\title{
Fruit Description and Evaluation of Five Treatments to Break Seed Dormancy of Brownlowia peltata Benth
}

\author{
Arief Noor Rachmadiyanto, Peniwidiyanti, \\ and Prima Wahyu Kusuma Hutabarat
}

Center for Plant Conservation Botanic Garden-Indonesia Institute of Science, J. Ir. H. Juanda 13, Bogor, Indonesia

\section{Abstract}

Brownlowia peltato Benth. is a native tree from Borneo, in its germination problem was physical dormancy due to the hard pericarp of the fruit. The study aimed to evaluate five treatments for breaking the seed physical dormancy and the fruit description. The experiment was using Randomized Complete Block Design (RCBD) with four different temperatures of water immersion, a scarification, and control. The fruit of $B$. peltato was a woody follicle; belong to yellow green group $148 \mathrm{~A}$ in color; $29.64 \mathrm{~mm}$ in long; $21.62 \mathrm{~mm}$ in thickness; $29.86 \mathrm{~mm}$ in wide, with an average weight of $12.05 \mathrm{~g}$. Hot water immersion treatment of $40^{\circ} \mathrm{C}$ for $60 \mathrm{~s} ; 60^{\circ} \mathrm{C}$ for $60 \mathrm{~s}$ and $80{ }^{\circ} \mathrm{C}$ for $30 \mathrm{~s}$ could raise the fruit moisture content of $0.92 \%$ to $1.04 \%$. There was a significant difference on germination rate coefficient and coefficient of uniformity of germination among

Corresponding Author: Arief Noor Rachmadiyanto ariefnoorzo@gmail.com

Received: 11 February 2017 Accepted: 08 March 2017 Published: 26 March 2017

Publishing services provided by Knowledge E

(a) Arief Noor Rachmadiyanto et al. This article is distributed under the terms of the Creative Commons Attribution License, which permits unrestricted use and redistribution provided that the original author and source are credited.

Selection and Peer-review under the responsibility of the ICBS Conference Committee.

G OPEN ACCESS treatments. The mature seed does not have a physical dormancy once the carpel splits and create a slit (fruit opening).

Keywords: Brownlowia pellato Benth; dormancy; fruit; seed; viability.

\section{Introduction}

Here Brownlowia belongs to Tiliaceae family and currently according to APG III, along with Bombacaceae, Malvaceae and Sterculiaceae merge into Malvaceae. Brownlowio peltato Benth. of the subfamily Brownlowioideae, is a small tree which is native to Borneo. The wood has been used for furniture and housewares. The fruit or seed is eaten as fresh fruit and used as a source of oil for perfumery by locals [1]

Brownlowio peltato is mainly propagated by seed since it produces a lot of fruit in recemes. Brownlowia's fruit is woody follicle with rough hard pericarp. However, hard seed pericarp of the fruit may cause slow and erratic germination and emergence. We expected this hard pericarp was water-impermeable which causing physical dormancy (PY) in the seed germination. Physical dormancy occurs due to the cover of fruit and seed with hard water permeability. It may well be, due to the presence of woody walls of fruits or seeds [2]. Fabaceae, Malvaceae s. lat. (including Bombacaceae s. str., Sterculiaceae s. str. and Tiliaceae s. str.), and Rhamnaceae has been confirmed as 
families of PY [3]. They mentioned seeds of Luehea speciosa, Luehea seemannii, Apeiba aspera, Apeiba tibourbou (Tiliaceae s. str.) were assigned to dormancy class PY.

Mechanical scarification, chemical (acid) and immersion in hot water/ heat treatment are two popular treatments to open the seed wall or break physical dormancy. The result of a study by Bien \& Lan [4] recommended that seeds of $B$. tubularis need sowing immediately after harvest and was treated with $60^{\circ} \mathrm{C}$ water immersion for an hour before sowing. It indicated that $B$. tubularis possibly had a physical dormancy that needs to break before sowing.

Two specimens of B. peltato which are cultivated in Bogor Botanic Garden are flowering twice a year and produce abundant of fruits. The seedlings that are growing naturally from seed have never been observed related to the seed characters and dormancy. The germination character of $B$. peltato is also poor known. Therefore, the aim of this study was to evaluate five treatments to break the physical dormancy of the seed along with the fruit description.

\section{Materials and Methods}

\subsection{Materials and methods}

More than 240 fruits of Brownlowia peltata Benth. were collected from a collection specimen of Bogor Botanic Garden at May 4th, 2015. The fruit age or maturity was unknown and indehiscent (not split yet). The fruit and seed examination were conducted in Treub Laboratory and Seed Bank Unit of Bogor BG. The observation of germination conducted in trial nursery of Bank Seed Unit from May to June 2015. In fruit and seed description examination, we used 30 fruits that were chosen randomly. The variables included weight of 1000 units, fruit color (using RHS color chart), dimension size of fruit and seed.

For germination test, we used a Randomized Complete Block Design (RCBD) with total six treatments for breaking physical dormancy: four different temperatures of water immersion, a scarification treatment, and a control. Each treatment had four replicates and each replication contained 10 fruit. The water temperatures were $40^{\circ} \mathrm{C}$ for $60 \mathrm{~min} ; 60^{\circ} \mathrm{C}$ for $60 \mathrm{~min} ; 80^{\circ} \mathrm{C}$ for $30 \mathrm{~min}$; and $93^{\circ} \mathrm{C}$ for $1 \mathrm{~min}$. After the fruit had got treatments, all of the seed were immersed in room temperature water for $24 \mathrm{~h}$ to encourage imbibition. Sowing of the seeds conducted in boxes of sand media under tree shade with regular watering. Environment data was also collected throughout the observation including temperature, relative humidity, and light intensity. 


\subsection{Data analysis}

Calculation of the seeds moisture contents on fruit was using formulas below:

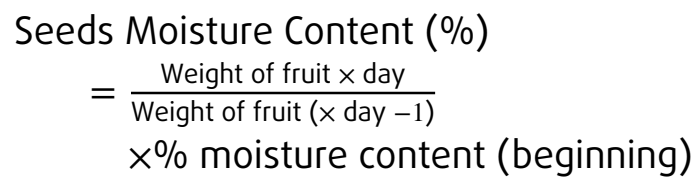

Calculation of germinating rate was using formulas as follows [5]:

$$
\begin{gathered}
\text { Germination rate }=\frac{\text { number of seeds germinated }}{\text { number of seeds on tray }} \times 100 \% \\
\text { Germination Rate Coefficient }=\frac{\sum n}{n \times t} \\
\qquad T=\frac{\sum(t \times n)}{\sum n}
\end{gathered}
$$$$
\text { Coefficient of uniformnity of germination }=\frac{\sum n}{\sum\left\{(T-t)^{2} \times n\right\}}
$$

Descriptions: $t: \times$ day; $n$ : number of seed; $T$ : Total number of days of germination.

Data analysis used Fisher Test (F-test) at a real level 0.05, followed with Duncan Multiple Range Test at a real level 0.05 , when the F-test showed significant different.

\section{Results and Discussion}

\subsection{Fruit and seed descriptions}

Based on the examination, the fruit of $B$. peltata belongs to follicle type, oval, slightly flattened, sometimes irregular, woody with a line of dehiscence dividing the carpel into two parts. It contained a single seed that at maturity the fruits dry and dehisces on the line of dehiscence into two carpels [6], but in this case, the seed did not release and was separated from carpel. The carpel was persistent until the seed germinating.

The seed husk (pericarp) consists of three layers, the outer layer (exocarp) was hard woody layer with gray-brown pubescent hair/scales; brownish green (yellow-green group-148 A-B) in color. The mesocarp was a thick woody fibrous layer. The endocarp represented the seed coat; thin and water-impermeable [7]. It had length of $2.96 \mathrm{~cm}$ $\pm 0.27 \mathrm{~cm}$; width of $2.99 \mathrm{~cm} \pm 0.25 \mathrm{~cm}$; thickness of $2.16 \mathrm{~cm} \pm 0.22 \mathrm{~cm}$. The weight of 1000 seeds was $11342.39 \mathrm{~g}$. The seed was off-white (ivory); flattened heart-shaped with the embryo was on the tip; $1.93 \times 1.81 \mathrm{~cm}$. Cotyledon was $0.49 \mathrm{~cm} \times 0.22 \mathrm{~cm}$ (see Figure 1). 


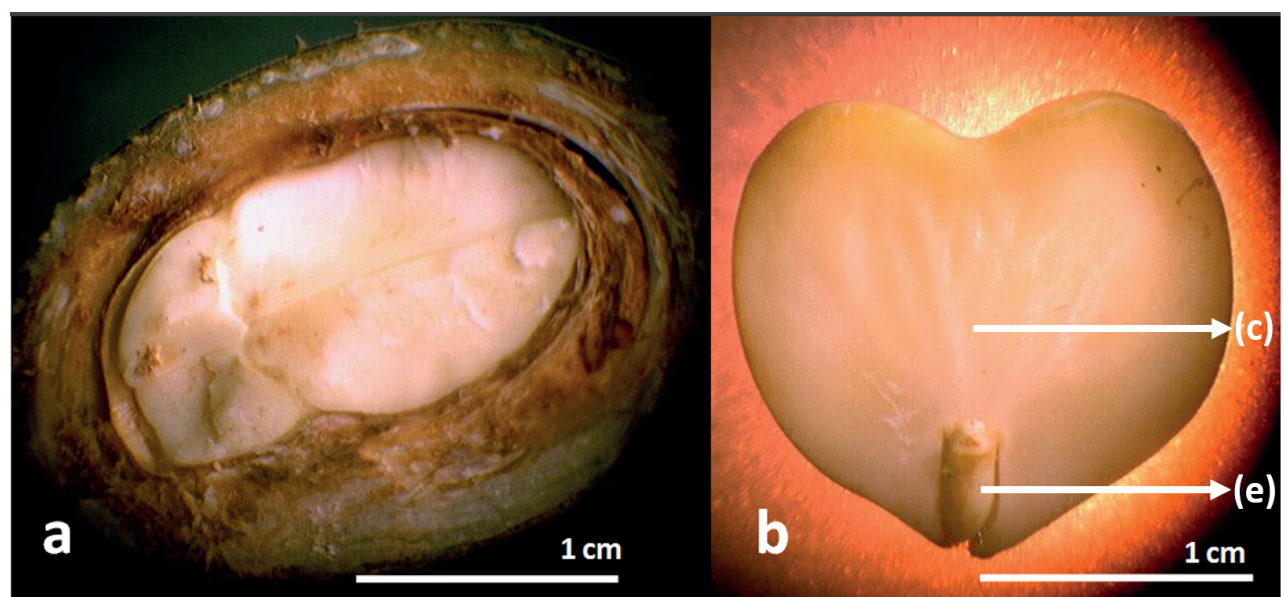

Figure 1: (a) Cross section slice of B. peltato fruit; (b) Bronlowio peltato seed: cotyledon (c) and embryo (e).

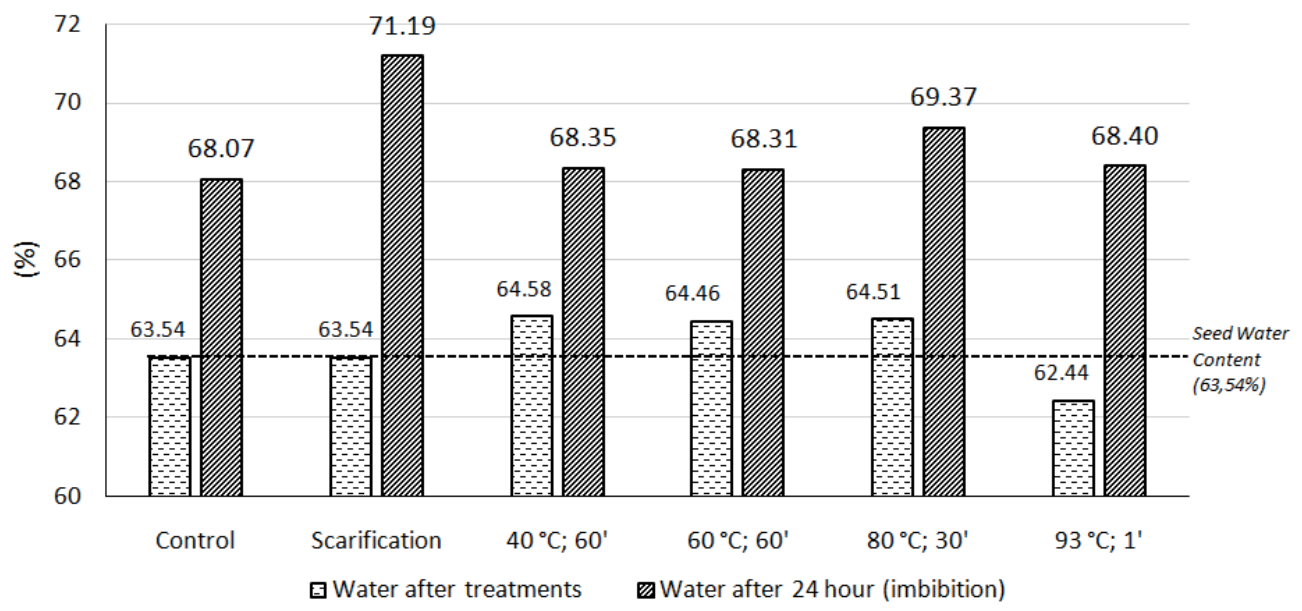

Figure 2: Imbibition rate of B. peltoto fruit after treatments and 24 hours imbibition.

\subsection{Imbibition rate}

Germination starts with imbibition, a process of water uptake of seed, caused by different water concentration gradient between seed and the environment. It changes the metabolic process of the seed and induces cell differentiation of the embryo. The more water that goes into the seed, the colloidal materials such as proteins are likely inflated and causing the split of seed husk.

The fruit weight was $11.74 \mathrm{~g}$ when collected with moisture content of $63.54 \%$. Volume of fruit changed after the treatments and $24 \mathrm{~h}$ imbibition. Figure 2 shows percentage of the change of fruit weight before-after treatment and after $24 \mathrm{~h}$ imbibition.

B. peltata fruit was floating at the beginning of water immersion due to its fibrous seed husk. After imbibition, some of the fruits were still floating and some of them were sunk. Hot water immersion treatment of $40^{\circ} \mathrm{C}$ for $60 \mathrm{~s} ; 60^{\circ} \mathrm{C}$ for $60 \mathrm{~s}$ and $80 \mathrm{C}$ for $30 \mathrm{~s}$ raised the fruit moisture content of $0.92 \%$ to $1.04 \%$ which is similar each other, 


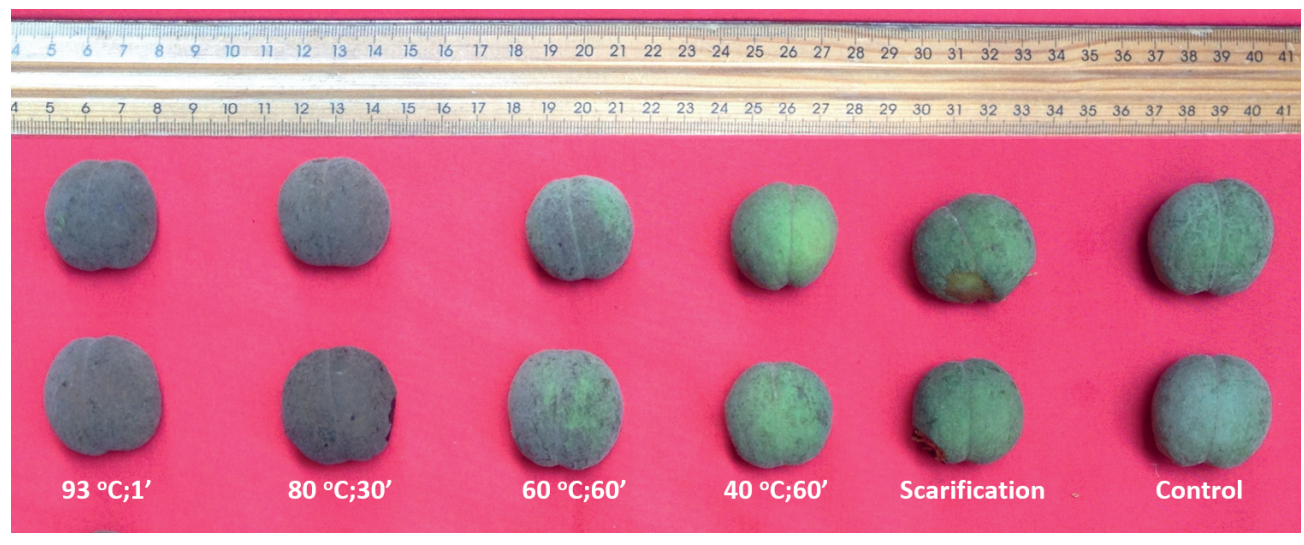

Figure 3: The discoloration of Brownlowia peltato fruit after hot water immersion treatments.

otherwise, another hot water immersion treatment of $93^{\circ} \mathrm{C}$ for one minute lowered the fruit moisture content up to $1.56 \%$ became $62.44 \%$. A decreasing percentage of fruit weight possibly caused by plasmolysis of pericarp cell were damaged due to high temperature. The higher the temperature of the water led discoloration of the outer husk became more brownish and blackened. Figure 3 shows the discoloration of the outer husk after hot water immersion treatments.

After $24 \mathrm{~h}$ imbibitions, the highest imbibitions rate occurred to the scarification treatment (71.19\%) and the lowest imbibitions rate occurred to control (68.07\%). Comparing among hot water immersion treatments, the treatment of $80^{\circ} \mathrm{C}$ for 30 led the highest imbibition rate of $69.37 \%$ while the other treatments of $40^{\circ} \mathrm{C}$ for $60 \mathrm{~s}, 60^{\circ} \mathrm{C}$ for $60 \mathrm{~s}$ and $93^{\circ} \mathrm{C}$ for $1 \mathrm{~s}$ led relatively similar imbibition rate. They are $68.35 \%, 68.31 \%$ and $68.40 \%$. Scarification treatment affected the water uptake of the seed before sowing. It indicated that the outer pericarp was impermeable. High temperature (up to $93^{\circ} \mathrm{C}$ ) was not effective enough to break the permeability of the pericarp.

\subsection{Seed germination}

Germination is influenced by some of the factors, either internal or external. The main external factor are water, oxygen, and temperature [8]. Outdoor temperature at the location of germination test was $23^{\circ} \mathrm{C}$ to $31.7^{\circ} \mathrm{C}$ in the morning and $31.4^{\circ} \mathrm{C}$ to $34.8^{\circ} \mathrm{C}$ in the afternoon. The containers was placed under canopy shade of Durio zibethinus, Cinnamomum burmannii, and a palm to imitate natural condition in forest. Humidity of germination media was maintenance by regular watering.

Germination type of $B$. peltato seed was epigeal. Primary root or radicle was the first part growing from the seed, followed by elongation of hypocotyl that lifted up the cotyledon and plumule. Sometimes the carpel persisted to the cotyledon and lifted up along with it [9]. Splitting of the carpel was a sign that cotyledon and embryo cell were swollen and developing because of sustainable water uptake. It happened 


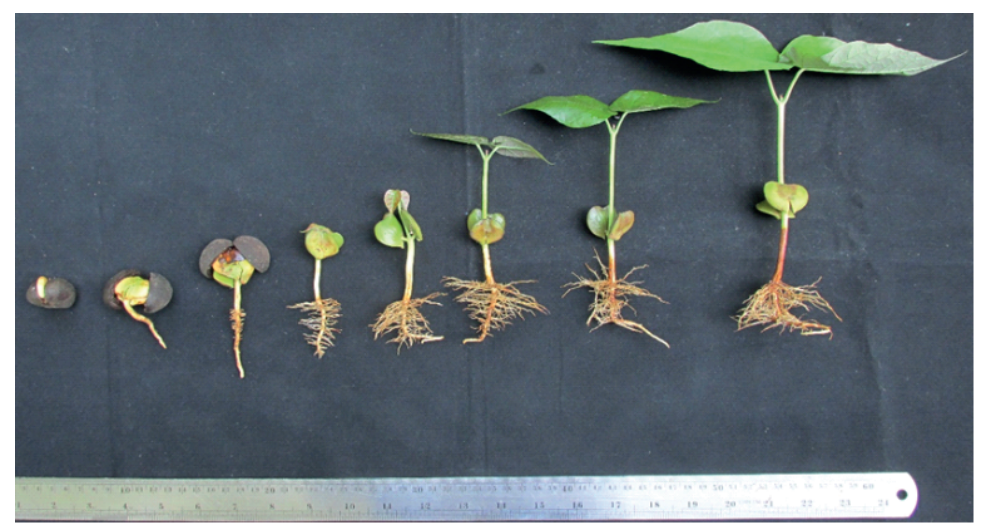

Figure 4: Stages of Brownlowia peltato germination.

\begin{tabular}{l|c|c|c} 
Treatments & Germination Rate Germination Rate Coefficient & Coefficient of uniformity of germination \\
\hline Control & $60.00 \mathrm{~b}$ & $0.1014 \mathrm{bc}$ & $0.0562 \mathrm{bc}$ \\
\hline Scarification & $52.50 \mathrm{~b}$ & $0.1582 \mathrm{C}$ & $0.0513 \mathrm{~b}$ \\
\hline Temp. $40^{\circ} \mathrm{C}$ & $60.00 \mathrm{~b}$ & $0.0762 \mathrm{~b}$ & $0.0845 \mathrm{C}$ \\
\hline Temp. $60^{\circ} \mathrm{C}$ & $10.00 \mathrm{a}$ & $0.1147 \mathrm{bC}$ & $0.0425 \mathrm{~b}$ \\
\hline Temp. $80^{\circ} \mathrm{C}$ & $0.00 \mathrm{a}$ & $0.0000 \mathrm{a}$ & $0.0000 \mathrm{a}$ \\
\hline Temp. $93^{\circ}$ & $0.00 \mathrm{a}$ & $0.0000 \mathrm{a}$ & $0.0000 \mathrm{a}$ \\
\hline Numbers followed by the same letter in the same column are not significantly different at
\end{tabular}

TABLE 1: Germination rate, germination rate coefficient and coefficient of uniformity of germination for each treatment.

mostly on the day 12 after sowing. After hypocotyl had stopped growing, the plumule was growing bigger became two opposite leaves along with epicotyl. The cotyledon shrank gradually after the plumule reaches the maximum size and started a new shoot. After the plumule reaches this maximum condition, we assumed that the germination was complete. It happened on the day 35 after sowing. Figure 4 shows the germination stage of $B$. peltoto.

Either scarification or low-temperature treatment $\left(40^{\circ} \mathrm{C}\right)$ did not raises germination rate significantly compared to control. The high temperature of water immersion treatment $\left(80^{\circ} \mathrm{C}\right.$ or more) had a tendency of damaging the seed instead of breaking the dormancy. According to germination rate coefficient, it showed that scarification treatment had the highest value (0.1558) compared to other treatment, but Duncan Multiple Range Test (DMRT) 0.05 results (Table 1) showed that scarification treatment and $60^{\circ} \mathrm{C}$ water immersion treatment was insignificant compared to control. Analysis of coefficient of uniformity of germination led to different result. The highest value was obtained by scarification treatment which means the treatment produced the most uniform germination of the seed among others. However, since it was not significantly different to control and $60^{\circ} \mathrm{C}$ treatment, we believe that those five treatments did not raise the uniformity of germination of the seed. 
Even though, the highest imbibition rate happened on the scarification treatment. It did not affect the germination rate but slightly affected to germination rate coefficient and coefficient of uniformity of germination. Germination rate was not influenced by any treatment of physical dormancy breaking, either high temperature or scarification. Therefore, we believed the seed of $B$. peltato did not have a physical dormancy like the early supposition, and it normally germinates once they reach maturity with or without carpel splitting.

Dehiscent habit of the mature fruit of $B$. peltato was not perfectly released the seed from the persistent carpel, but it obviously created a slit in order to let the seed directly exposed to water faster. This was a possibly natural habit to break physical dormancy of the woody carpel. Baskin et al. [7] reported that Malvaceae (including Bombacaceae, Sterculiaceae, and Tiliaceae) contain species that produce non-dormant seeds, but they did not mention the species in detail. This result also contradicted with the study of Bien $\&$ Lan [4] which reported the germination rate of $B$. tabularis was positively affected by $60^{\circ} \mathrm{C}$ water immersion for an $\mathrm{h}$ and continued with cold water immersion for an hour. It increased germination rate by $85 \%$ while control's germination rate of $69 \%$. The limitation of our study was unknown maturity or age of collected fruit. Study of Bien \& Lan [4] did not inform the condition of fruit carpel (whether splitted or not) and maturity of fruit as well.

\section{Conclusion}

Fruit of $B$. peltato is belong to follicle type with impermeable woody persistent carpel. The mature seed does not have a physical dormancy once carpel splits and creates a slit which exposes the seed to the open air. The seed can normally germinate (60\%) with or without some of the physical dormancy breaking treatments. Some hot water immersion treatments $\left(80^{\circ} \mathrm{C}\right.$ and above) can damage the seed and cause failure to germinate. To raise germination rate of the seed, further study is needed to determine the maturity of fruit when it is collected and determine of type dormancy of the seed other than physical dormancy such as physiological dormancy or other dormancy.

\section{Acknowledgements}

We would like to thank Dian Latifah for advising and permission to undertake fieldwork in her management area, Seed Bank Unit of Bogor Botanic Garden. We are also grateful for generous assistance provided by the qualified staff, Mimin and Aulia Hasan Widjaya. 


\section{References}

[1] Kew. Royal, "Botanic Garden," accessed, vol. 9, 2015, http://apps.kew.org/ecbot/specimen/64740.

[2] J. M. Baskin and C. C. Baskin, "A classification system for seed dormancy," Seed Science Research, vol. 14, no. 1, pp. 1-16, 2004.

[3] A. Sautu, J. M. Baskin, C. C. Baskin, J. Deago, and R. Condit, "Classification and ecological relationships of seed dormancy in a seasonal moist tropical forest, Panama, Central America," Seed Science Research, vol. 17, no. 2, pp. 127-140, 2007.

[4] P. Tran and R. Shaw, "Chapter 5 Forest: Catastrophic Flood and Forest Management in Vietnam," in Environment Disaster Linkages, vol. 9 of Community, Environment and Disaster Risk Management, pp. 79-99, Emerald Group Publishing Limited, , 2012.

[5] Draper Sr., LN. Bass, and A. Bould, "Seed science and technology. International Seed Testing Association," in Bould A. Seed science and technology. International Seed Testing Association, p. 13, Zurich, 1985.

[6] JG. Harris and MW. Harris, "Plant Identification Terminology: an illustrated glossary," in Plant Identification Terminology: an illustrated glossary, p. 216, Utah, Spring Lake, 2nd edition, 2001.

[7] J. M. Baskin, C. C. Baskin, and X. Li, "Taxonomy, anatomy and evolution of physical dormancy in seeds," Plant Species Biology, vol. 15, no. 2, pp. 139-152, 2000.

[8] PH. Raven, RF. Evert, and SE. Eichhorn, "Biology of plants. 6th printing," in Eichhorn SE. Biology of plants. 6th printing, p. 686, W.H. Freeman and Company, New York, 2003.

[9] L. Sutopo, Teknologi benih Seeds technology. 2nd ed. CV. Rajawali: Jakarta; 1988, p. 247 in Bahasa Indonesia. 